\title{
Histopathological study on the antifungal activity of Salix plant extract on some dermatophytes
}

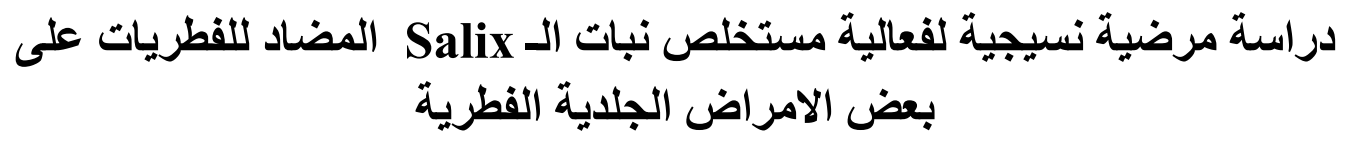

Kawkab, S.A.

*Al-Samarrae, $\mathbf{K}$

$* *$ B. Rabee

College of Medicine/ Al-Nahrain University

*Biotechnology Research Center/ Al-Nahrain University

** Ministry of Minerals and Industry

\section{Abstract}

The study was designed to determine the activity of methanolic Salix extract as an antifungal agent. Rabbits were divided into three groups. The first group represents the control (6) while the second and the third groups were infected with fungal inoculums of the rabbit skin. After development of skin lesion, the infected area of the second group was treated with Salix extract until healing. The histopathological study revealed recovery from infection in the infected animals, which manifested by well-developed epithelial tissue similar to the control group.

تمت دراسة فعالية مستخلص نبات methanolic Salix كمضاد للفطريات ـ قسمت الار انب الى ثلاث مجاميع ، الاولى تمثلت بمجموعة السيطرة (6) بينما المجموعة الثانية والثالثة عرضت للاصابة بالفطريات الجلدية ، عند

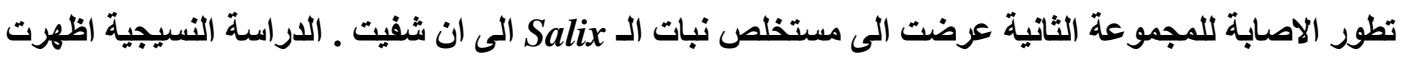
تحسن من الاصابة في المجاميع المصابة مقارنة بنسيج مجموعة السيطرة .

\section{Introduction}

A large number of drugs plant were used traditionally to treat various ailments all over the world including the Arabian countries [1].
Several spices of herbs have been known to posses antimicrobial activities. Many projects described the inhibitory properties of different active compounds including volatile oils, 
alkaloids, phenolics, \& others with their effect on a variety of microorganism [2].

Recently, the search for antibiotics from natural origin has markedly increased. However several plants have been screened for their fungitoxicity [3].

Salix is one of these plants which is considered to be the natural origin of the modern aspirin [4]. Previous studies indicated the presence of tannins and glycosides including salicine and its derivatives in this plant. Many flavonoids have been isolated from $\underline{\text { Salix }} \operatorname{spp}$ [5]. It is used as antipyretic,

\section{Materials and method}

1. Methanolic plant extract was prepared by maceration of the leaves (50)gm with $70 \%$ methanol for 24 hours, and then evaporated to dryness by rotary evaporator [7].

2. Animals:6 rabbits were divided into three groups. The first group represents the control (no treatment), while the rabbit of the second and the third group were infected with fungal inoculums on the skin of the rabbits. Skin lesions were developed after seven days. The infected areas were treated with Salix extract (until antiphlogestic, analgesic and for pain caused by inflammation [2].

Dermatophytosis are a group of superficial fungal infection caused by mold fungi of the genera Trichophyton, Microsporum \& Epidermatophyton, which share the ability to invade stratum corneum \& keratinized structures such as hair and nails derived from epidermis [6].

This study is an attempt of histological study on the effect of Salix extract as an anticfungal agent on skin infection caused by epidermatophyton.

healing) for hiostopathological study in comparison with that of infected but not treated.

3. Tissue preparation: tissue specimens were fixed using immersion fixation for 4 hours in $2.5 \%$ phosphate buffered gluteraldehyde (PH.4) then post fixed with $1 \%$ osmium tetraoxide for 1 hour and processed for plastic embedding. Semi-thick sections were sectioned for light microscope study, stained with $1 \%$ methylen blue basic fuchsine [8]. 


\section{Results}

1. First group: animals infected with Epidermophyton . all infected animals showed pathological changes with adherence of fungus to keratinocytes, through the stratum granulosum of the epidermis. The roofs and contents of the vesicles usually contain fungal hyphae. The epidermis exhibited atrophy of rete

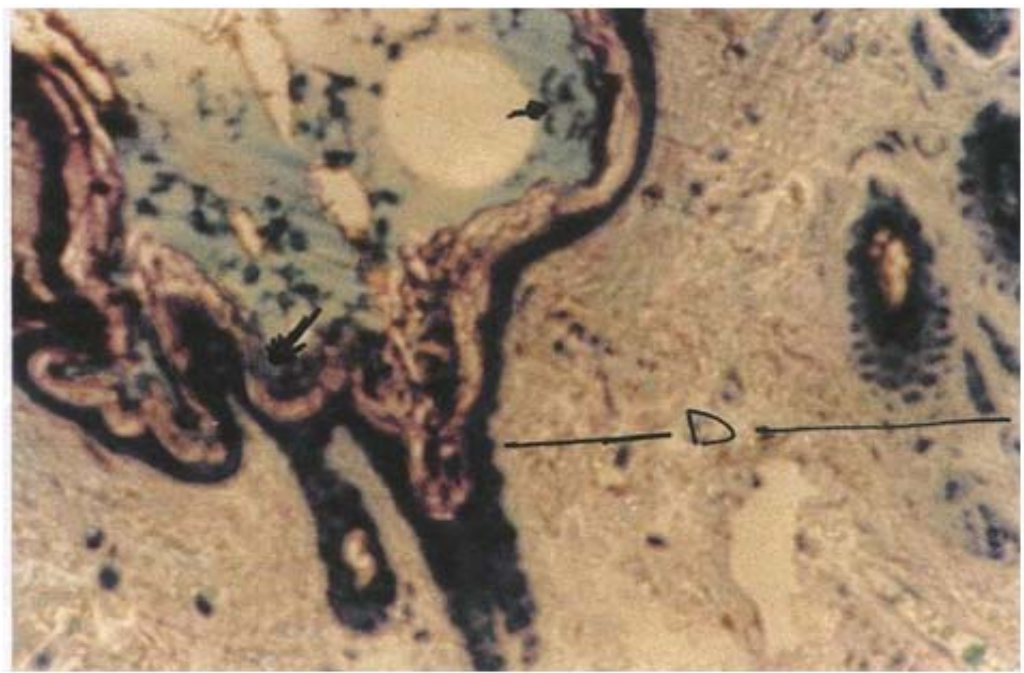

Fig(1) : Plastic section of skin in animal infected with the fungus(400x)

$$
\text { Note }
$$

$$
\begin{aligned}
& \longrightarrow \text { Fungal hyphae } \\
& \longrightarrow \text { : Damaged epidermis } \\
& \text { : Dermis }
\end{aligned}
$$
D Dermis

other features are acute lesions ridge Fig.(1).

characterized by vesicles which extend

The underlying dermis manifested adundant fungal hyphae. The skin appendages especially hair follicles appeared altered. The hair bulb and hair papilla were converted into keratinized layer Fig.(2). 


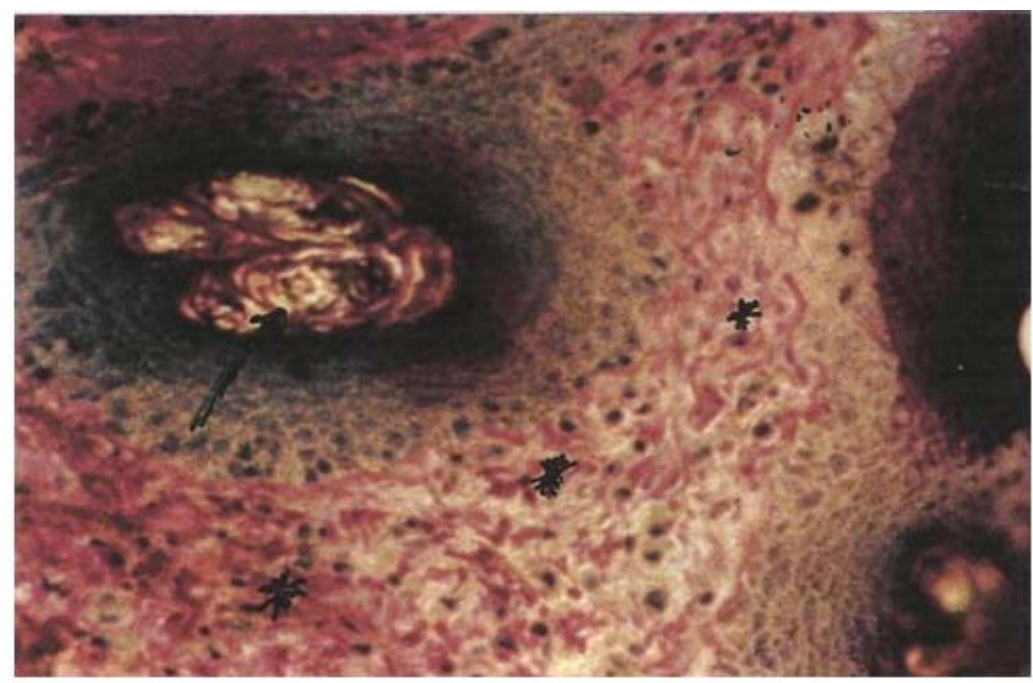

Fig(2): skin of animal infected with dermatophyte. (400x)

Note $\longrightarrow$ the penetration of fungal hyphae and damaged hair follicle

Secondary to the cellular damage, there is an acute inflammation reaction in the vicinity. This manifested markedly with degenerated epidermis and dermis with an exudates containing moderate number of lymphocytes Fig.(3).

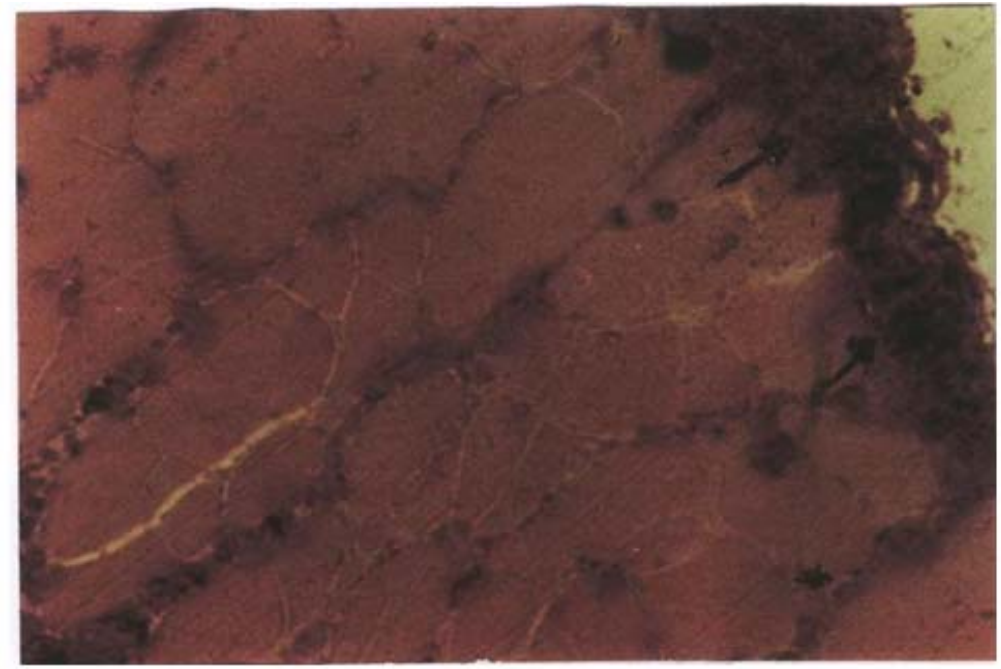

Fig (3): Dermis of infected animal. (400x).

Note the degenerated dermis layer

Lymphocyte infiltration in the muscular layer

2. Second group: infected animals treated with Salix extract has shown recovery from infection which manifested by well developed epithelial tissue similar to the control group Fig. $(4,5)$. 


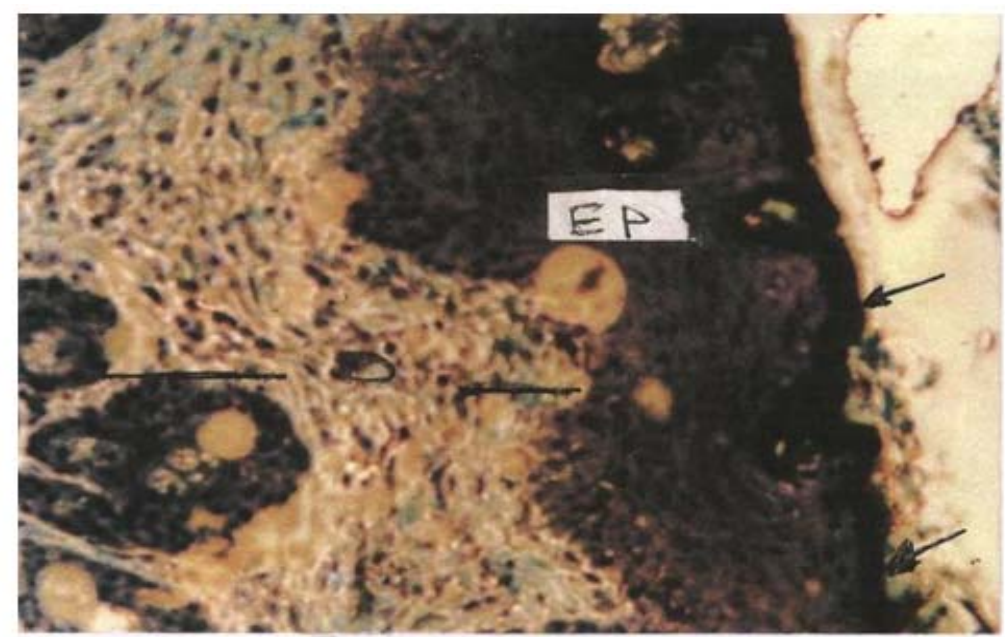

Fig (4): Skin in control animal group (400x)

Ep: Epidermal layer

D: Dermis

$\longrightarrow$ : Keratinized layer

Stratum germinativum of epidermis with vasodilatation at the basal layer include a lymphocytic infiltration to the Fig.(5). dermo-epidermal junction associated

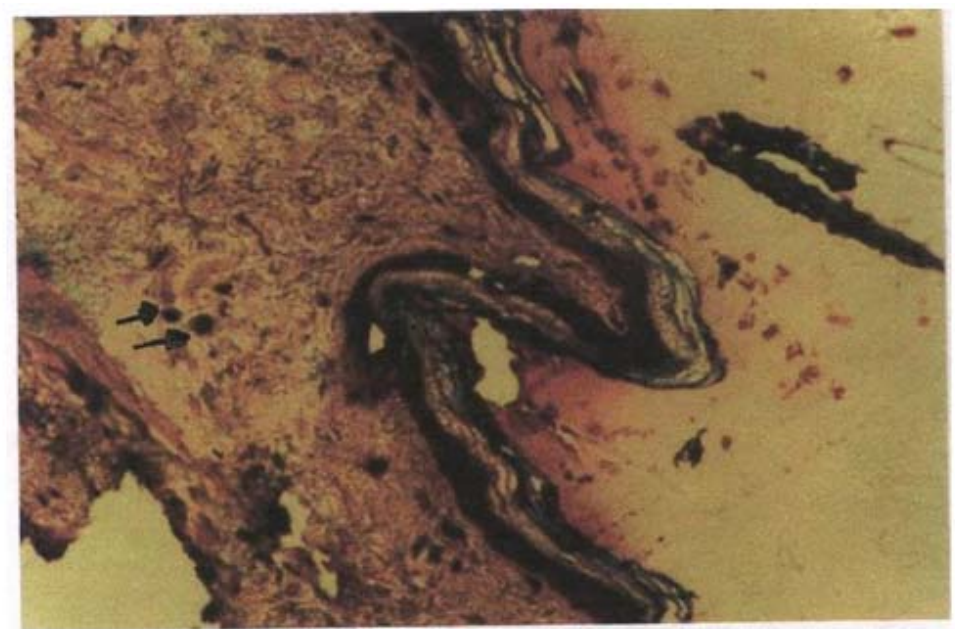

Fig (5): infected skin, treated with Salix extract (400x) Note the appearance of inflammatory cells $\longrightarrow$

Portions of fibroblasts and macrophages were frequently observed among the collagen fibers. Regeneration \& healing of the skin is also characterized by the presence of muscles and increase in the number of blood veessels. Lymphocyter also was observed. Fig. $(6,7)$. 


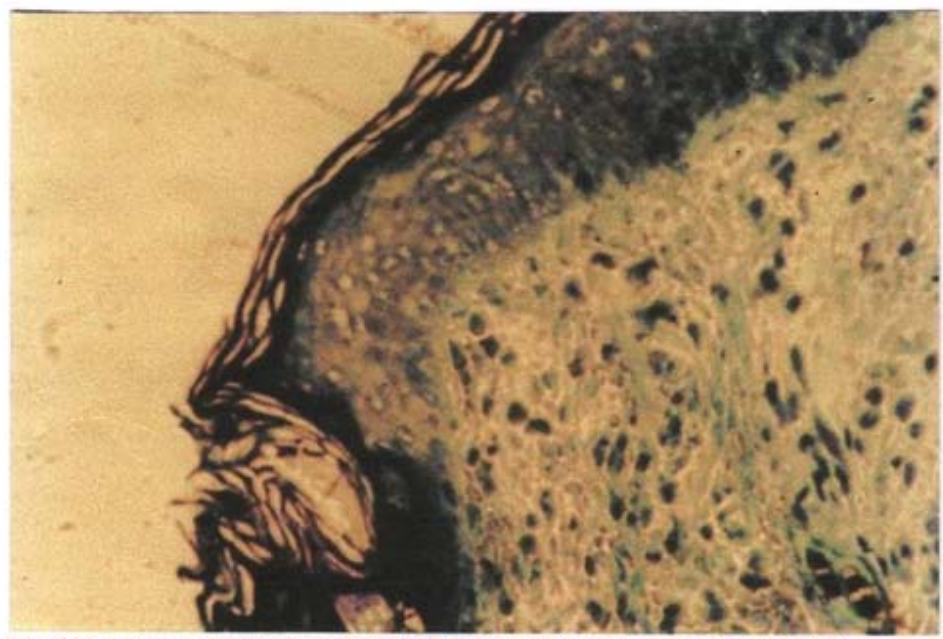

Fig (6): section with normal skin, healing after treatment with Salix extract. (400x)

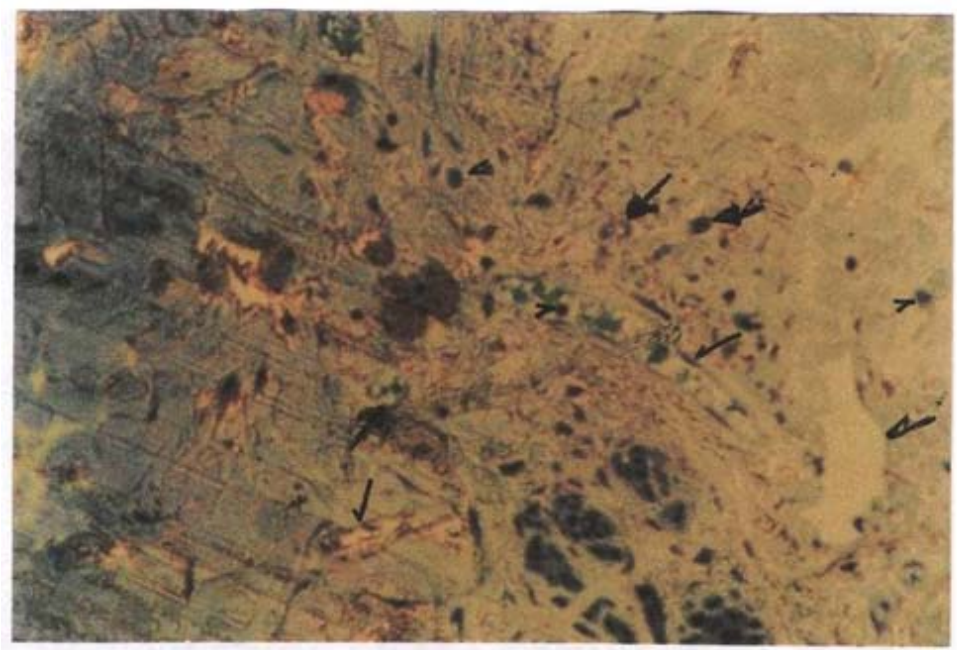

Fig (7): Section of healed skin after treatment with Salix extract (400x)

Note of Blood vessels

And presence of lymphocyte

\section{Discussion}

Our finding support the model proposed by [9] who suggested that systemic responses that result in an eczematous reaction of the epidermis. dermatophytes could lead to local or 
Increased epidermal turnover could be a part of eczematous reaction through the process of shading the dermatophyte and repairing epidermal damage.

Salix extract assists the naturalization and removal of organisms from the area by its antifungal activity against drematophytes, as well as stimulates increased in epidermal turnover. Thus, the damaged area would tend to revert to normal and presumably healing takes place slowly, returning the keratinized epidermis to normal structure [3].

The fibroblast tend to arranged collagenous fibers in the derim layer invading into muscles and large amount on inflammatory cells (lymphocytes, neutrophils, plasma cells) infiltrating that assist the healing process $[10,11]$.

As well as, Salix extract improve the tissue blood supply and have anti

\section{References}

1. Evans, W(1988). Pharmaco gnosy $.14^{\text {th }}$ ed. UK.

2. Robbers, J.E ; M. K. speed; e; \& V.E.Tyler (1966). Pharmacognosy \& pharmacobiotechnology Lea\&Febiger book p.337. inflammatory effect to promote epidermal repair in the skin.

From this study we can conclude that Salix extract exerts a marked antifungal activity against dermatophytes.

The activity of Salix extract may be attributed to the flavonoids or glycoside extracted by methanol [7, 12, 13]. Methanolic extract and flavonoid of Salix was active against wood fungi [12].

Three general mode of action for plant extracts were recognized according to [14]

1. Inhibition of microbial cell well formation or biosynthesis of some protein.

2. Disruption of DNA metabolism.

3. Alteration of normal function of the cellular membrance.

Many researches pointed that tannins, flavonoid and glycosides are major groups of plant products considered as ant microbial agents [15].

3. Al-Samarrae, K; kawkab, S.A. and B. Rabee (2005). Histological study on the anntiungal activity of Salvia (hexane extract) on some dermatophytes, Journal of science, collage of science, Al- 
Nahrain university (accepted for publication in 2006)

4. PDR for herbal medicine 2003 Medical Economics Company.ed.(internet).

5. Meier, B., Sticher, O., sulcunen, T.R.(1988). Pharmaceutical aspects of the use of willows in herbal remedies. Planta medica, 54(6) :559-560.

6. Zurita, I.D., and Hay, R,J.(1987). Adherance of dermato phyte microconidia and arthro conidia in vitro.J. invest .Ddermatol. 189: 529-534. 7. الخفاجي ، باسمة ربيع (2000) تأثير مستخلصات نبات سم الفراخ والميرمية و الصفصاف على نمو بعض الفطريات الجلدية - رسالة ماجستير - الجامعة وسئ ولئ المستتصرية - كلية العلوم . 8. القيسي، كوكب سليم (1988) ـ دراسة بالمجهر الالكتروني للخلايا الظهارية وفاعليتها الافرازية في غدة التوثة للفئران بعد تثبيط هرمون النمو ـ رسالة ماجستير - كلية العلوم - جامعة بغداد.

9. Jones, H.E. ; Reinhardt, J.H. ; and Rinaldi, M.G.(1974). Acquired immunity yo dermatophytes. Arch Dermatol 109 : 840-848.
10. Kamide, R.(1997). Histopathological diagnosis by skin biopsy. NipponRinsho.55:(9): 2259-2261.

11. Ergun, T. ;Gurbuz, O. ;Harvell, J.; Jorizzo, and white, W.(1998). The histopathology of : a chronologic study of skin hyperreactivity in Beheers disease. Int.J.Dermatol 37 (12) :929933.

12. Maltervd, K.M.(1985) flavonoide from the wood of Salix copera as inhibitors of wood destroying fungi. J. Nat. Prod. 48:559-563.

13. Al-Janabi, A.A. (2004). Effects of Calendula officiinalis extracts on the growth of some pathogenic microorganisms. MSc.thesis (collage of sciences). Al-Nahrain University, Iraq

14. Hugo, W.B. and A.D Russell, 1989, pharmaceutical microbiology. $4^{\text {th }} \mathrm{ed}$.

15. السامر ائي، خلود وهيب . باسمة ربيع الخفاجي

(2002) تأثير مستخلص نباتي سم الفراخ

Salivia و والميرامية Withania Somnifera officinalis Scopulariopsis العر اقية للاحياء المجهرية ، المجلد 14 العدد (1) . 